\title{
THE SOCIAL JUSTICE IMPLICATIONS OF THE US DRUG WAR
}

\section{Matthew Robinson ${ }^{1}$ and Maggie Jones ${ }^{2}$}

1 Appalachian State University, Department of Government and Justice Studies, Boone, NC 28608 robinsnmb@appstate.edu

2 Appalachian State University, Department of Government and Justice Studies, Boone, NC 28608

\section{ABSTRACT}

jonescm6@email.appstate.edu

\begin{abstract}
In this paper, the authors outline key facts pertaining to the US drug war, including its stated goals and objectives, and then offer an assessment of the empirical evidence related to its (in)effectiveness in achieving these goals. Data illustrate that drug use is not down, that availability of drugs is not down, that the price of drugs is not down, that access to drug treatment has not increased, and that deaths and illnesses associated with drugs use are not down. The authors also identify major costs associated with national drug control policy and weigh these against its benefits. This analysis permits a conclusion with regard to whether the drug war is a "good" or "bad" policy. Finally, the authors utilize major theories of justice to identify whether the drug war is consistent with social justice. The analysis shows that the drug war does not commonly accepted definitions of social justice.
\end{abstract}

\section{Indexing terms/Keywords}

Social justice, drug war, drug policy, justice

\section{Academic Discipline And Sub-Disciplines}

Criminal Justice, Criminology

\section{SUBJECT CLASSIFICATION}

Drug war, social justice

\section{TYPE (METHOD/APPROACH)}

Secondary data analysis

\section{Council for Innovative Research}

Peer Review Research Publishing System

Journal: Journal of Social Sciences Research

Vol. 7, No. 1

jssreditor.cir@gmail.com

www.jssronline.com 


\section{INTRODUCTION}

US national drug control policy—commonly referred to as the drug war-has increasingly faced serious criticisms from activists, reform groups, and even serious scholars on both the left and right sides of the political spectrum (Gray, 2001; Miron, 2004, Vance, 2014). As evidence has mounted that the drug war has failed to meet its goals of reducing drug use and saving lives, and as studies and media analyses have consistently illustrated enormous costs associated with US drug control policy, more and more people are calling for change (Benavie, 2008; Provine, 2007; Robinson and Scherlen, 2014). Further, public opinion has shifted toward decriminalization, legalization of marijuana, as well as ending mass incarceration for drug offenders. For example, a recent Gallup Poll found that $58 \%$ of Americans think that marijuana should be legalized (Gallup, 2013), and even the Office of National Drug Control Policy is pushing to reduce imprisonment of low-level drug offenders (ONDCP, 2014). Most scholarly analyses of the drug war focus on the ability of federal drug control agencies to meet their stated goals, especially with regard to the overriding goal of reducing illicit drug use among young people and adults (Gray, 2001; Inciardi, 2007; MacCoun and Reuter, 2001). Media examinations tend to focus on human elements of the drug war, stories of real people whose lives have been negatively impacted by being apprehended, convicted, and incarcerated for sometimes relatively minor crimes (Brown, 2014). While both of these approaches brush up against issues related to social justice - making sure that advantages, prizes, and rewards as well as disadvantages, burdens, and costs in society are distributed appropriately (Miller, 2003) —neither is explicitly about social justice. In fact, there are very few accounts of US drug control policy that fully reveal social justice implications ofthe drugwar.In this paper, the authors attempt to outline the major social justice implications of US drug control policy. After first establishing the empirical realities of the nation's drug war-including whether it meets its stated goals and objectives and whether its benefits outweigh its costs-the authors then turn to whether the drug war is consistent or inconsistent with different theories of justice. Major theories of justice are introduced and then utilized to assess the degree to which the drug war is socially just. The implications of this will be discussed later in the paper.

\section{WHAT IS THE DRUG WAR AND HOW LONG HAS IT BEEN FOUGHT?}

America has always had a war on drugs of some kind, including wars on alcohol, opium, heroin, marijuana, crack cocaine, methamphetamines, and so on (Inciardi, 2007). Yet, it was not until 1971 when a formal war on drugs was declared by President Richard Nixon. And even though the Drug Enforcement Agency (DEA) has been in existence since 1973, it was not until November 1988 that a federal agency was created by Congress to organize all national efforts by numerous agencies to fight the drug war. This agency is the Office of National Drug Control Policy (ONDCP), commonly referred toas the "drug czar's" office. ONDCP states goals and objectives of national drug control policy, creates a budget for the dozens of agencies that carry out different elements of the drug war, and communicates (via published reports, its website, and other means) with members of Congress and the public about whether the goals and objectives are being met and why. Each year, ONDCP publishes is National Drug Control Strategy as the primary report through which it attempts to illustrate whether the drug war is working. Importantly, studies find the agency selectively presents statistics, manipulates visual graphs and figures, and essentially "lies" with statistics to suggest its goals and objectives are being met even in cases when they are not being met (Robinson and Scherlen, 2007, 2014). This, itself, has significant social justice implications.

\section{What are the Goals of the Drug War?}

The goals of the drug war have changed over the years with each presidential administration. This is problematic because it makes evaluating the efficacy of the drug war over time difficult. Yet, US drug control policy has consistently been aimed at one primary goal as well as other secondary goals; that primary goal is to reduce drug use and drug abuse among both young people and adults. Secondary goals have included things such as reducing availability of drugs by disrupting illicit drug markets, healing drug abusers by providing treatment to those who need it, reducing health and social costs associated with drug use and abuse, among others. The kinds of health and social costs associated with drugs that ONDCP wants to reduce include death, sickness, and economic costs associated with drug abuse (e.g., productivity losses) (Robinson and Scherlen, 2014). Importantly, some of the secondary goals help achieve the primary goal of reducing use. For example, reducing availability of drugs by disrupting illicit drug markets will ideally make it more difficult for people to obtain drugs, increase prices, reduce purity of drugs, and thereby reduce use. Healing drug abusers by providing treatment will also ideally reduce drug use as people stop using drugs(Robinson and Scherlen, 2014).

\section{Performance Toward the Goals of US Drug Control Policy}

Figure 1 illustrates the goals and objectives of the drug war under President Obama and ONDCP Director Gil Kerlikowske. Note that there are just two goals, including reducing drug use and decreasing costs associated with drug use. Measurable objectives related to the first goal include reducing drug use among 12-17 year olds and 18-25 year olds as well as reducing chronic use by adults. Measurable objectives associated with the second goal include reducing drugrelated deaths, illnesses, and drugged driving. 


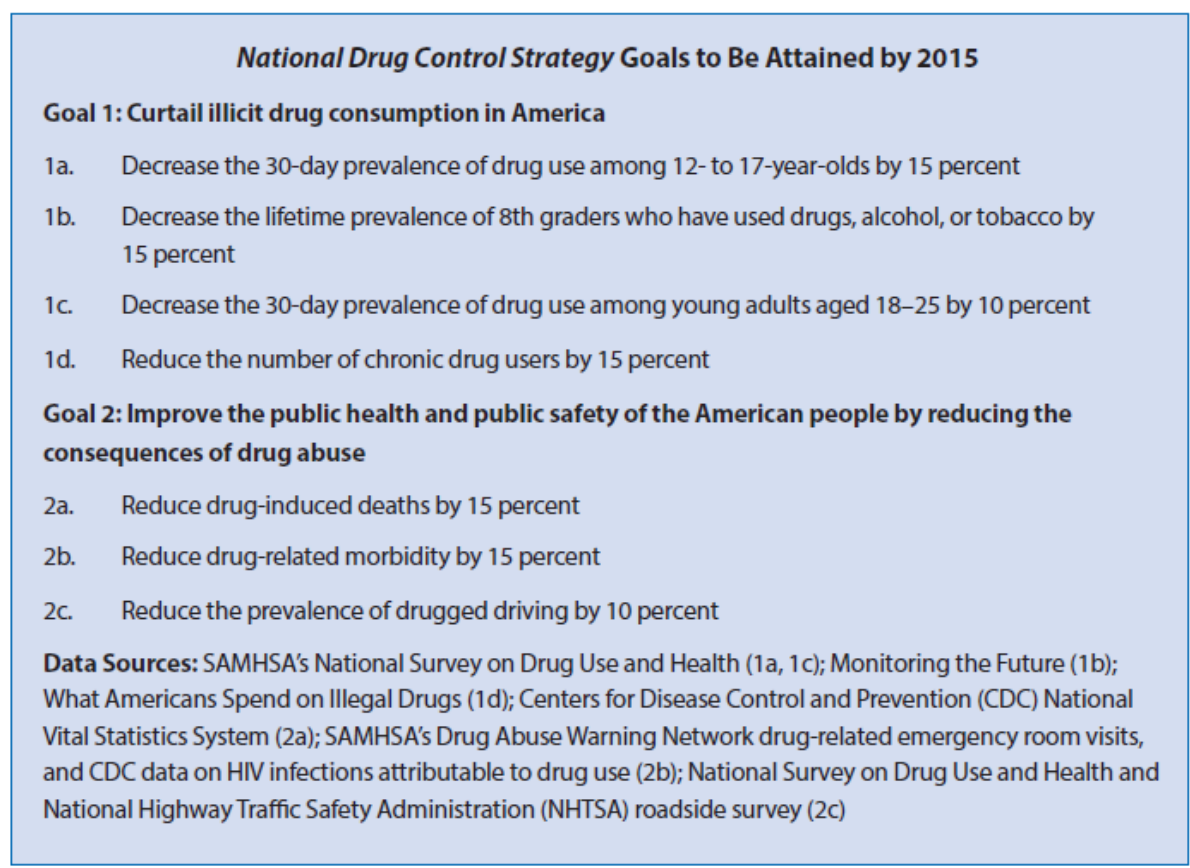

\section{Fig 1: Goals and Objectives of the Drug War under President Barack Obama}

ONDCP hopes to achieve these goals and objectives by 2015 , so it is too early to assess whether the agency will ultimately meet them. Unfortunately, previous research has shown that ONDCP changes its goals and objectives with each new president; this is because each president selects his own ONDCP director (aka the "drug czar") and identifies itself as being responsible only for trends in drug use and related measures during the time-period for which that president and drug czar are in office (Robinson and Scherlen, 2007). Further, with each administration, ONDCP shifts the time period across which its goals and objectives should be measured. For example, the focus of ONDCP under President Bill Clinton was on the period 1992-1998 while under President George W. Bush it was the period 2000-2008, and for President Barack Obama it is 2009-2015. We posit that taxpayers and policy-makers are interested in whether the drug war achieves its goals over the long term, not during the term of any one president. Further, we assert that it makes the most sense to evaluate the drug war since the inception of the federal agency that leads it-ONDCP. If one focuses on the historical goals of the drug war across administrations, it is possible to determine whether ONDCP has achieved its goals and objectives since its inception in November 1988. In the section that follows, we assess US drug control policy in terms of whether it has been able to achieve the goals that have historically guided the US drug war-reduce drug use among youth and adults, reduce the perceived availability of illicit drugs, provide treatment to those who need it, and reduce health and social costs associated with drugs.

\section{Reducing Drug Use}

There are two major sources of data to establish prevalence of drug use trends in the United States-the National Survey of Drug Use and Health (NSDUH), and Monitoring the Future (MTF). NSDUH is a national household survey that reports findings of a representative sample of Americans ages 12 years and older. MTF is a national school-based survey of $8^{\text {th }}$, $10^{\text {th }}$, and $12^{\text {th }}$ graders. Each survey is conducted every year and both are used to establish drug use trends in the US. hile neither captures completely all drug use, they are thought to be valid in establishing drug use trends (Robinson and Scherlen, 2007).Starting with MTF, the data show that, since the creation of the Office of National Drug Control Policy (ONDCP) in November 1988, drug use among $8^{\text {th }}, 10^{\text {th }}$, and $12^{\text {th }}$ graders is not down. Importantly, drug use trends for $8^{\text {th }}$ and $10^{\text {th }}$ graders are only available since 1991 , so analyses of MTF data for $8^{\text {th }}$ and $10^{\text {th }}$ graders must begin in 1991; trend data from 1991 through 2013 show that drug use for $8^{\text {th }}, 10^{\text {th }}$, and $12^{\text {th }}$ graders was higher in 2013 than it was in 1991 , as shown in figure 2. Data on $12^{\text {th }}$ graders is available from 1975; trend data from 1975 through 2013 show that drug use among $12^{\text {th }}$ graders was lower in 2013 than 1979 when drug use peaked, but this is mostly due to a large decline in drug use that occurred in the 1980 s, prior to the establishment of ONDCP. Drug use among $12^{\text {th }}$ graders was higher in 2013 than the year when ONDCP was created (1988). 


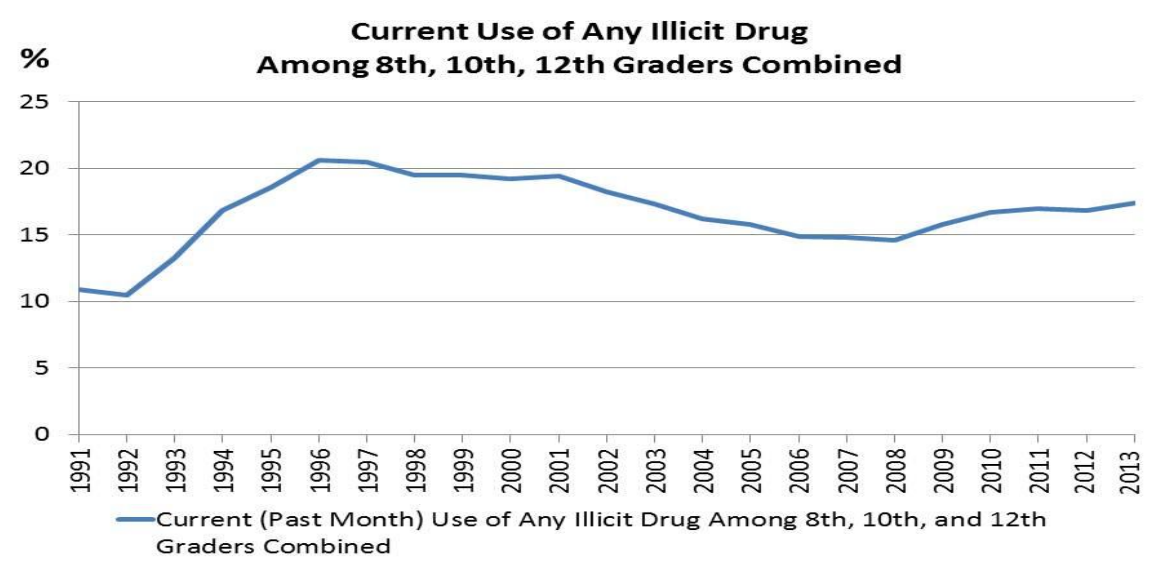

Source of data: http://monitoringthefuture.org/data/13data/13drtbl21.pdf

Fig 2: Drug Use Trends among Young People, MTF

The increase in drug use among $8^{\text {th }}, 10^{\text {th }}$, and $12^{\text {th }}$ graders is driven largely by use of marijuana, as use of other drugs declined from 1991 to 2013. For example, among $12^{\text {th }}$ graders, use is down for inhalants, hallucinogens, LSD, cocaine, and amphetamines. Yet, some other forms of drug use are rising. For example, non-therapeutic use of prescription drugs-commonly referred to as psychotheraepeutics-is increasing, as shown in figure 3 . This is especially troubling because drugs such as narcotics, sedatives, and tranquilizers lead to physical addiction and overdose deaths (NIDA, 2014).

Moving on to the other source of data on drug use, data from NSDUH are available from 1991, but because of two changes in survey methodology in 1999 and 2002, one should not compare recent data with any past data prior to 2002. ONDCP (2014) explains: In 1999, the survey methodology changed from a paper-and-pencil interview (PAPI) to a computer-assisted interview (CAI). Estimates based on the new CAl methodology are not directly comparable to previous years. In 2002, the survey was renamed the National Survey on Drug Use and Health, and methodological changes were implemented that significantly affected reported prevalence rates. Therefore, estimates since 2002 are not directly comparable to previous years.

Trend data from NSDUH, illustrated in figure 4, show that drug use in 2011 was higher than in 2002. Further, even with the methodological changes in the survey, reflected by the vertical lines in the figure, there is no reason to believe that drug use is down over a longer term, other than since 1979 when drug use peaked in the US.

Data specific to young adults (ages 18-25 years) and adults (26 years and older), presented by the Substance Abuse and Mental Health Services Administration within the US Department of Health and Human Services (but not depicted here), show that drug use among young adults and adults is not down and was fact slightly higher in 2012 than 2002.

Data specific to young adults (ages 18-25 years) and adults (26 years and older), presented by the Substance Abuse and Mental Health Services Administration within the US Department of Health and Human Services (but not depicted here), show that drug use among young adults and adults is not down and was fact slightly higher in 2012 than 2002. 


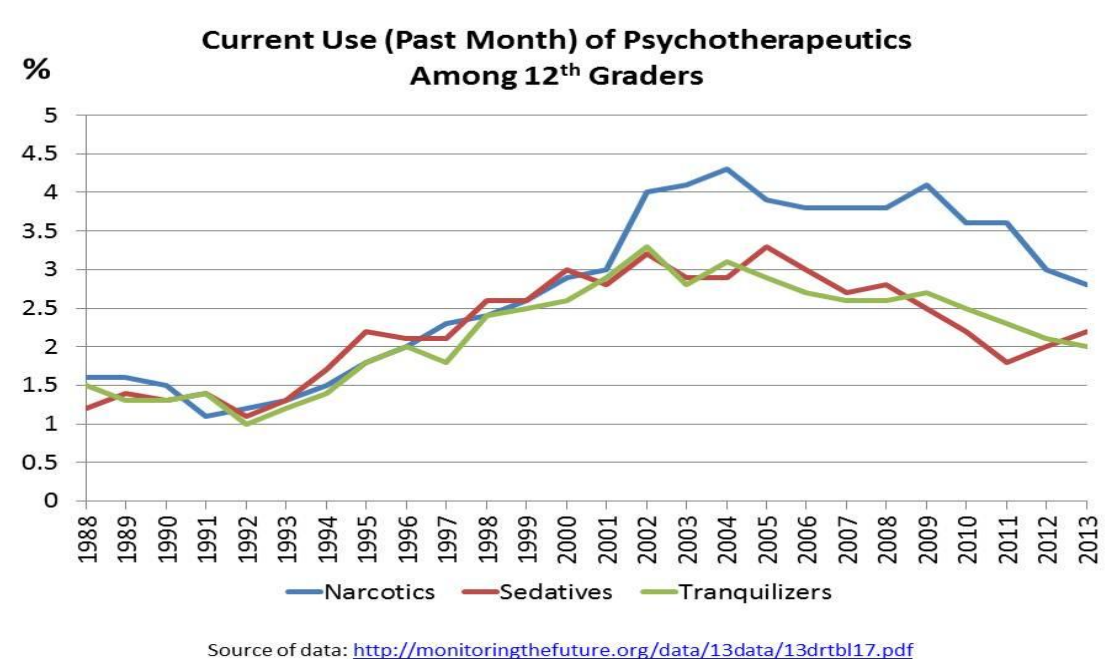

Fig 3: Psychotherapeutic Use Trends among Young People, MTF
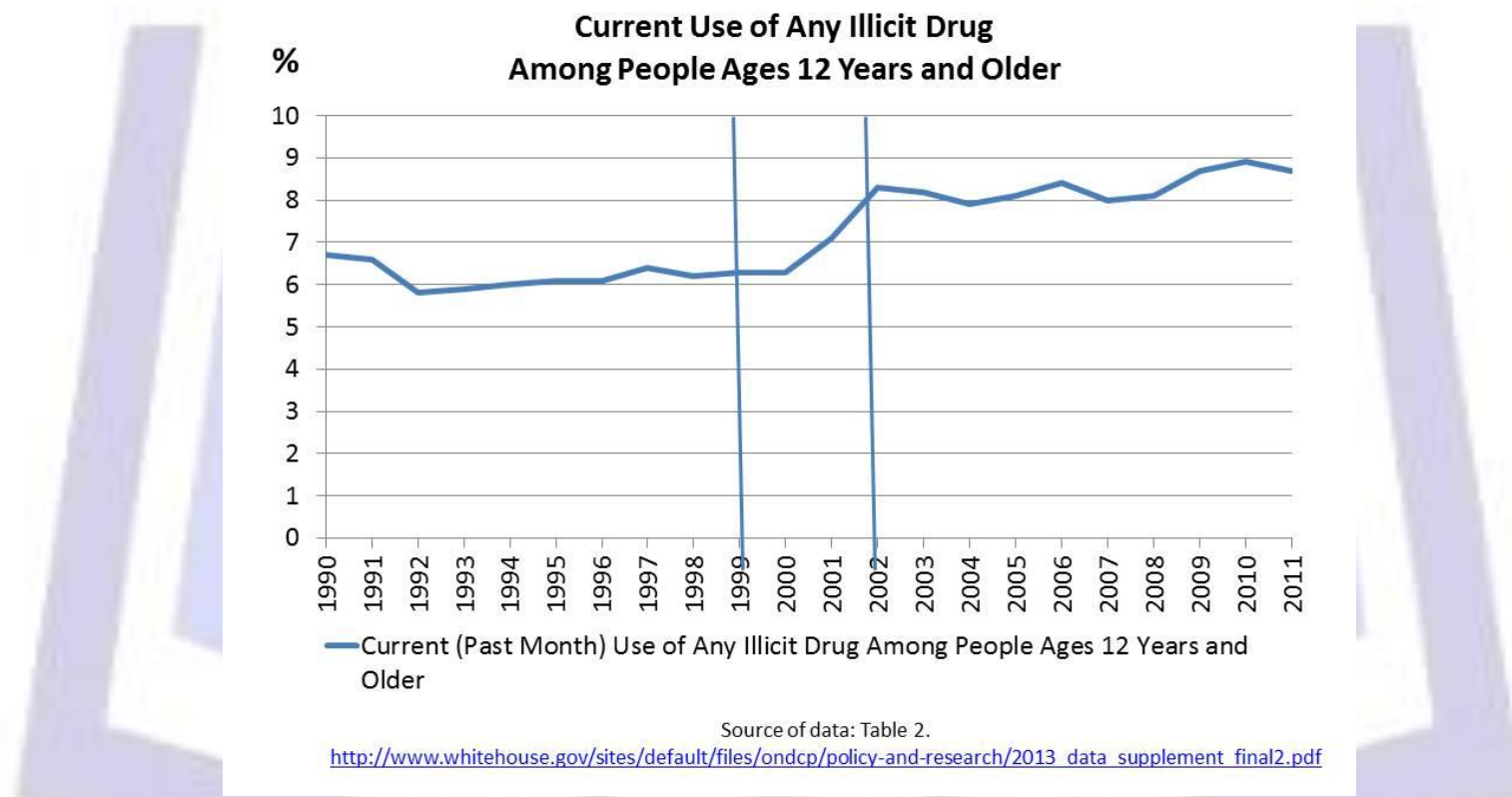

Fig 4: Illicit Drug Use among People Ages 12 and Older, NSDUH

Taken together, MTF and NSDUH data show that US drug control policy-the drug war-fails to achieve its most important goal of reducing illicit drug use among young people and adults. Importantly, the data used in this analysis are the same data used by ONDCP in its own assessments of the drug war, and in some cases the data literally come from the ONDCP website as part of its data supplement to the National Drug Control Strategy; we thus know ONDCP officials are aware of these realities. That drug use tends to rise and fall in spite of US drug control efforts is further evidence that the drug war does not meaningfully impact drug use. For example, drug use climbed in the 1970s, peaking in 1979, then declined until the late 1980s at which point it began to rise again. Drug use rose throughout the 1990s and then declined again in the 2000s, whereas now it is rising again. Throughout all these years, the drug war raged on, and with every year the budget for the drug war increased annually. This is further evidence that national drug control policy is ineffective.

\section{Reducing Drug Availability}

A secondary goal of US drug control policy is to disrupt illicit drug markets so that drugs will be less available to young people and to adults, which should ultimately drive up prices and thereby reduce drug use. Various measures are available to assess market disruption efforts, including estimates of total overall production potentials of some drugs such as heroin and cocaine in foreign nations, total production potential of some drugs such as marijuana in the US, total consumption of drugs by weight, and the number and weight of drugs seized by various law enforcement agencies (Boyum and Reuter, 2005; Inciardi, 2007). None of these measures provide an accurate assessment of actual drug 
availability and in fact such estimates are often modified after their release by the government (Robinson and Scherlen, 2014). Thus, we simply report data on perceived availability of various drugs among students from MTF. Data on $12^{\text {th }}$ graders are shown in figure 5 . We report data only on $12^{\text {th }}$ graders since use among $12^{\text {th }}$ graders is higher than among $10^{\text {th }}$ graders and $8^{\text {th }}$ graders; this suggests $12^{\text {th }}$ graders are most informed about whether illicit drugs are easily available or not. These data illustrate that most forms of illicit drugs were perceived as slightly less available in 2013 than in 1989. Specifically, the following drugs are perceived as being less available by $12^{\text {th }}$ graders: marijuana, LSD, cocaine, heroin, amphetamines, sedatives, and tranquilizers. Narcotics and Ecstasy are perceived as being more widely available.

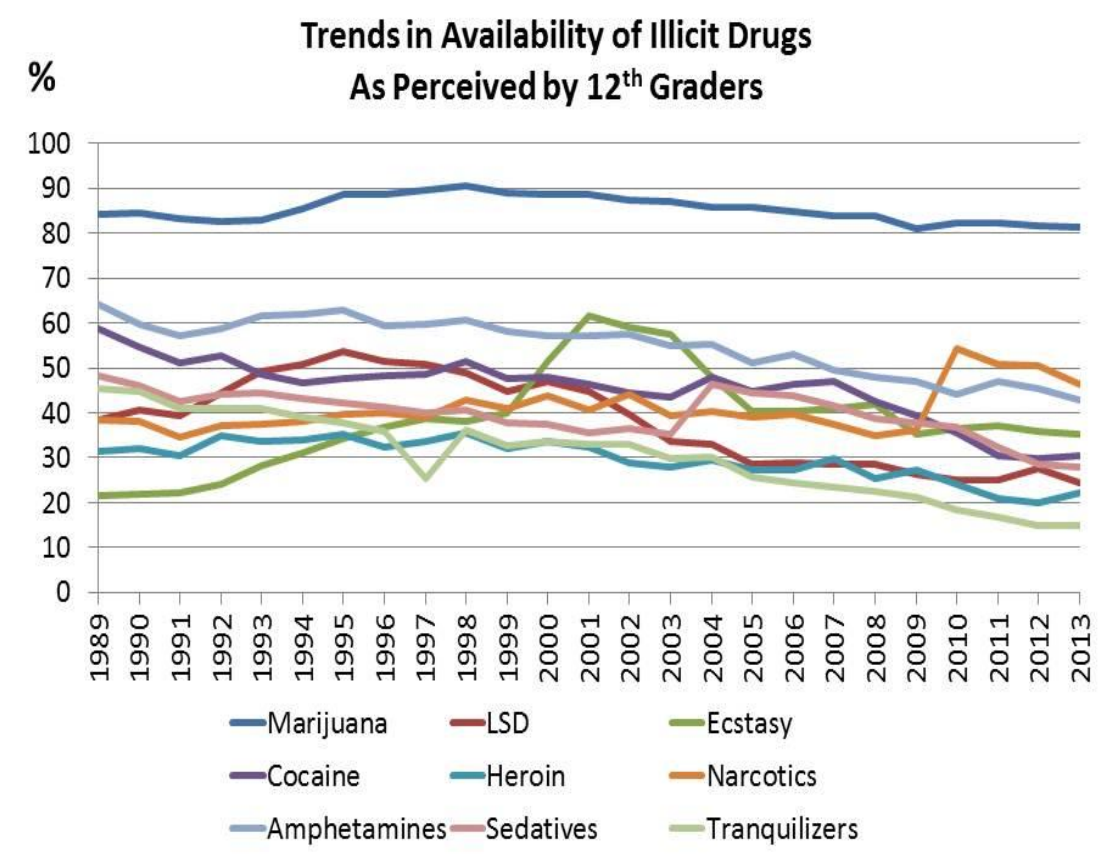

Source of data: $\underline{h t t p: / / m o n i t o r i n g t h e f u t u r e . o r g / d a t a / 13 d a t a / 13 d r t b l 21 . p d f ~}$

Fig 5: Perceived Availability of Illicit Drugs among Young People, MTF

Efforts to reduce availability of illicit drugs are thus not entirely in vain. Yet, it should be noted that many drugs are still perceived as widely available, especially marijuana, which is perceived to be "fairly easy" or "very easy" to obtain by more than $80 \%$ of $12^{\text {th }}$ graders. More importantly, reductions in availability have not produced reductions in drug use among young people, as shown earlier. Thus, this benefit of US drug control policy seems to have no meaningful impact on use

rates, which makes it inconsistent with ONDCP's overriding goal to reduce drug use. Importantly, this may owe itself to other realities associated with drugs not shown in figure form in this analysis. Recall that national drug control policy aims to drive up prices for illicit drugs as well as disrupt purity so that ultimately drugs are more pricey and less appealing to users; this is achieved by eradicating drugs at their foreign and domestic sources, and by seizing drugs at the border and on the streets of America. Incredibly, data from ONDCP - offered as a data supplement to the annual National Drug Control Strategy-show that the price of almost every drug has fallen significantly from 1989 to the present day, and the purity of drugs has simultaneously risen during this time (Robinson and Scherlen, 2014). That drugs are cheaper and better now than in the past may help explain why drug use has not fallen, even as they are perceived as slightly less available.

\section{Healing Drug Users (Increasing Drug Treatment)}

Another goal of US drug control policy is to heal drug abusers-i.e., provide treatment to those who need it.Data from NSDUH, shown in figure 6 and available only back to 2002 due to the methodological changes noted earlier, show that the vast majority of people deemed to be in need of treatment do not receive it. Specifically, about $85 \%$ of people who need drug treatment do not receive it. ONDCP admits this owes itself largely to a lack of opportunities for individuals to enter into quality and affordable treatment programs, even as the National Institute on Drug Abuse (NIDA) claims that "treatment works" (NIDA, 2014). The term "treatment gap" is used to describe the fact that most people who need drug treatment in the US do not receive it. 


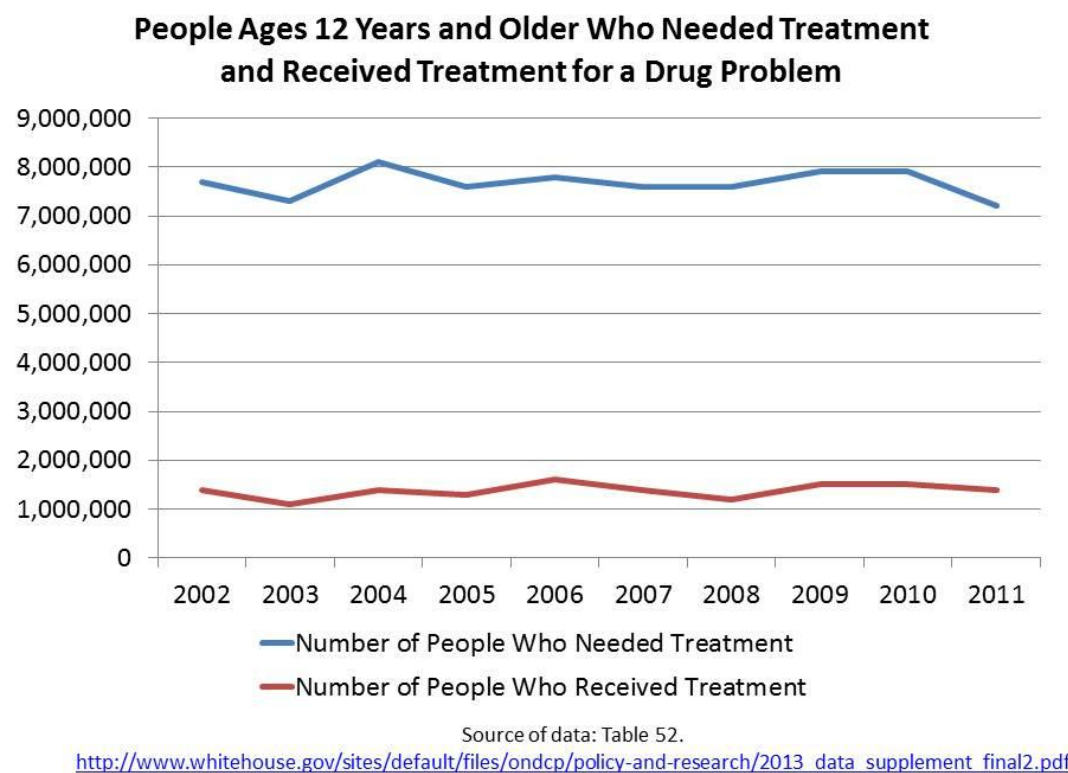

Fig 6: The Treatment Gap

Of one thing we are confident, the number of people entering treatment over time is not increasing. For example, data from Treatment Episode Data Set (TEDS) show that there were 1.6 million admissions for drug abuse treatment in 1997, and 1.8 million in 2010 (these data included alcohol and illicit drugs and are not specific to individuals but rather to admissions, as one person can be admitted more than once in any year). It is not at all controversial to acknowledge that the drug war fails to meet its goal of healing drug users through treatment. In fact, ONDCP has repeatedly acknowledged this reality; in the past it blamed users for being in denial and currently it acknowledges that effective treatment options are just not widely available (Robinson and Scherlen, 2014). This is partially because $59 \%$ of funding for national drug control spending is devoted to supply-side measures aimed at reducing illicit drug supplies through law enforcement, military, and foreign spending efforts and only $41 \%$ is devoted to demand-side measures aimed at reducing drug use through prevention and treatment. The FY 2013 budget request for ONDCP to fund all drug war activities totaled $\$ 25.6$ billion, and only $\$ 9.2$ billion is for treatment. This makes up only $36.3 \%$ of the drug war budget, and funding for treatment includes not only actual treatment services for those in needbut also money for research on treatment (ONDCP, 2014). US taxpayers have simply not devoted sufficient resources to treatment services to make them available to all who need them.

\section{Reducing Health and Social Costs of Drug Use and Abuse}

Finally, another goal of US drug control policy is to reduce costs associated with drug use and abuse. Over the years, ONDCP has stated numerous measurable objectives related to this goal, including: reducing the economic burden on society associated with drug abuse; reducing drug-related morbidity or illness; and reducing drug-related deaths.

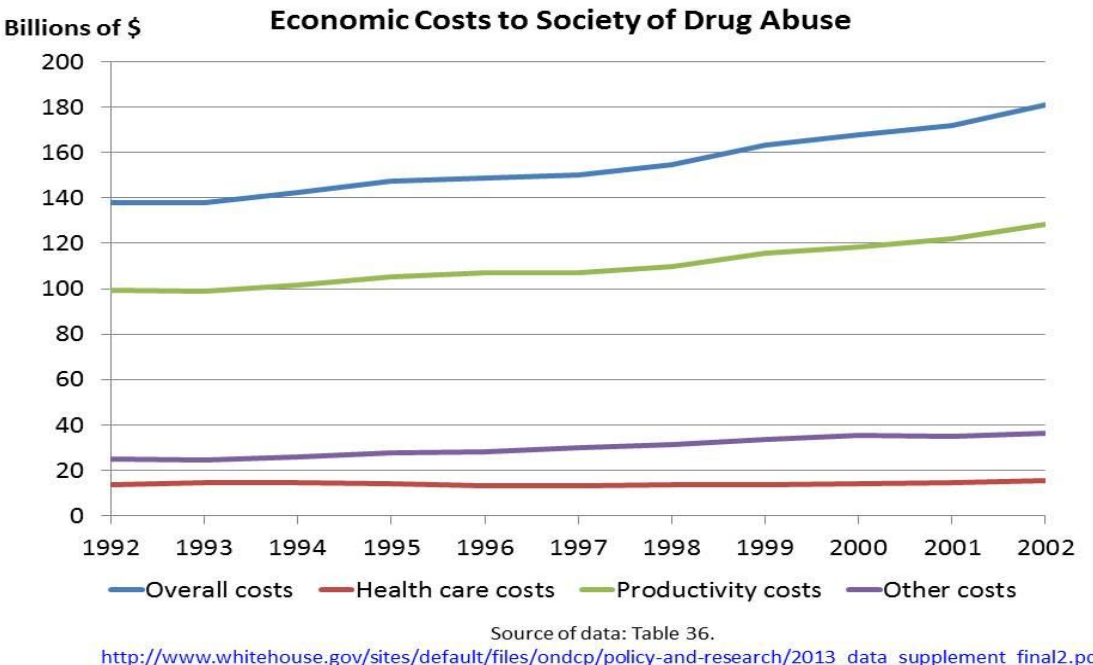

Fig 7: ONDCP's Estimates of Costs to Society of Drug Abuse 
Starting with economic costs, figure 7 shows that the economic costs of drug abuse are steadily rising over time; these data come from ONDCP's report, The Economic Costs of Drug Abuse in the United States. This is clearly inconsistent with ONDCP's goal of reducing costs of drug abuse. While many have taken issue with the validity of such data (e.g., the largest share of costs are deemed losses in productivity owing to drug abusers who lose income because of being unable to work due to drug abuse) (Bennett, 2014), the point is they come from ONDCP; this means ONDCP is clearly aware that it is not meeting its goal here.

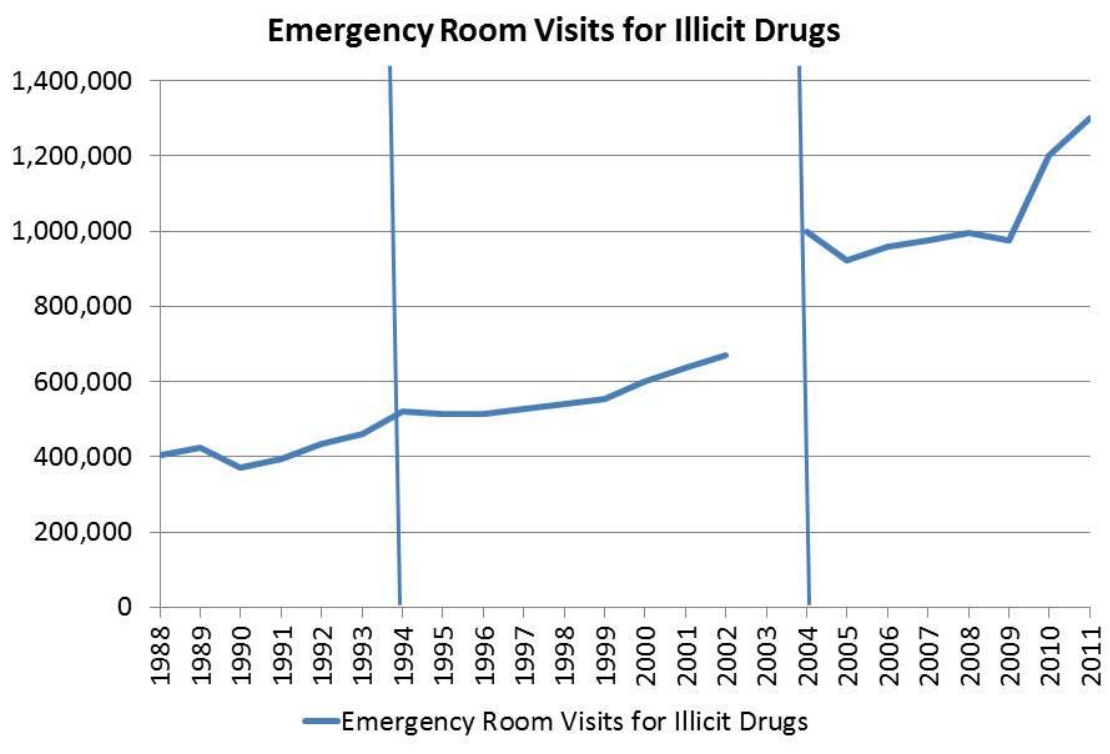

Source of data: Tables 40,41

http://www.whitehouse.gov/sites/default/files/ondcp/policy-and-research/2013 data supplement final2.pdf

Fig 8: Emergency Room Visits for Illicit Drugs

Data from the Drug Abuse Warning Network (DAWN), shown in figure 8, illustrate that emergency room visits for illicit drugs are rising over time; this is one indicator that illnesses associated with illicit drugs are not declining. The vertical lines in the figure represent a recalculation in data and then a redesign in the methodology of DAWN that make comparing data in later years with earlier years inappropriate. In spite of these changes, it is clear that emergency room mentions of drugs are rising rather than falling, inconsistent with ONDCP's goal of reducing health costs of drug abuse.

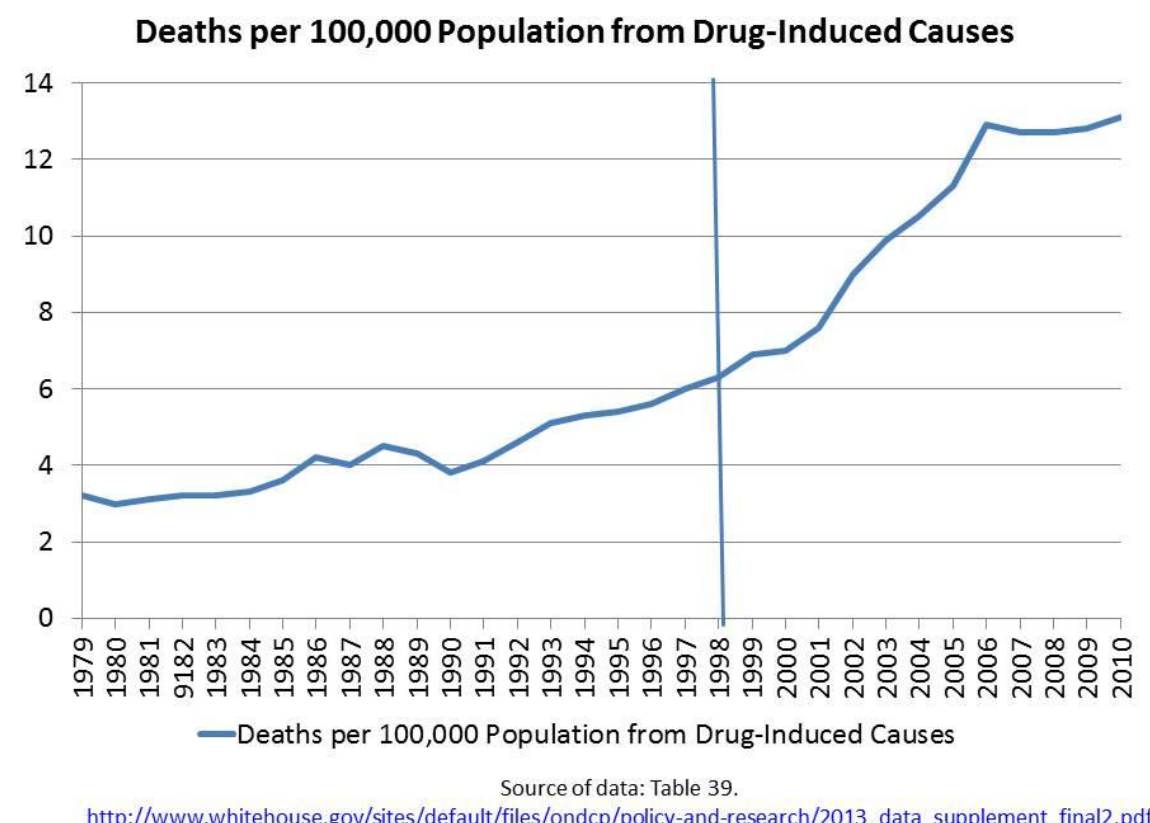

Fig9: Deaths Attributable to Illicit Drugs 
Similarly, data from National Vital Statistics show that deaths attributable to illicit drugs are also rising over time, as illustrated in figure 9. According to ONDCP, drug-induced deaths include one category of deaths that result from "drug psychoses, drug dependence, nondependent use of drugs not including alcohol and tobacco, accidental poisoning by drugs, suicide by drugs, assault from poisoning by drugs, and poisoning by drugs of undetermined intent (whether accidentally or purposely inflicted)." Another category includes "specific mental and behavioral disorders due to psychoactive substance use, accidental poisoning by drugs, intentional self-poisoning (suicide) by drugs, assault (homicide) by drugs, poisoning by drugs of undetermined intent and a number of causes of death explicitly linked to drug use."The vertical line in the figurerepresents the adoption of a new edition of disease classifications from the World Health Association (WHO).Not only are the number of deaths attributable to drugs rising over time, so too is the rate of drug deaths per 100,000 people as well as the rate of drug deaths per 100,000 users. This means deaths attributable to drug use are rising not because there are more people in society or because there are more drug users, but instead it means that drug use itself is becoming more deadly over time. This could result from users using more deadly drugs (e.g., prescription drugs) and/or the fact that the purity of illicit drugs is rising, making drugs potentially more deadly. Taken together, these data show that US drug control policy - the drug war-fails to reduce health and social costs of drug use and drug abuse. Not surprisingly, scholarly assessments of US drug control policy consistently show this to be the case. Further, they also indicate that the costs of the drug war are extremely high and outweigh the meager benefits offered (Mironand Waldock, 2010). Costs in criminal justice include major investments by agencies of police, courts, and corrections to attempt to disrupt drug markets and reduce drug use. Figure 10 illustrates that the percentage of all arrests that are for drug crimes has generally risen over time; this is a significant cost of national drug control policy.

As for the courts, the largest percentage of criminal cases at both the state and federal levels are for drug offenses. In the latest years for which data are available, drug cases made up 33\% of all convictions in state courts in 2006 and $33 \%$ of all convictions in federal courts in 2008 (Bureau of Justice Statistics, 2008). This, too represents a significant cost of US drug control policy.

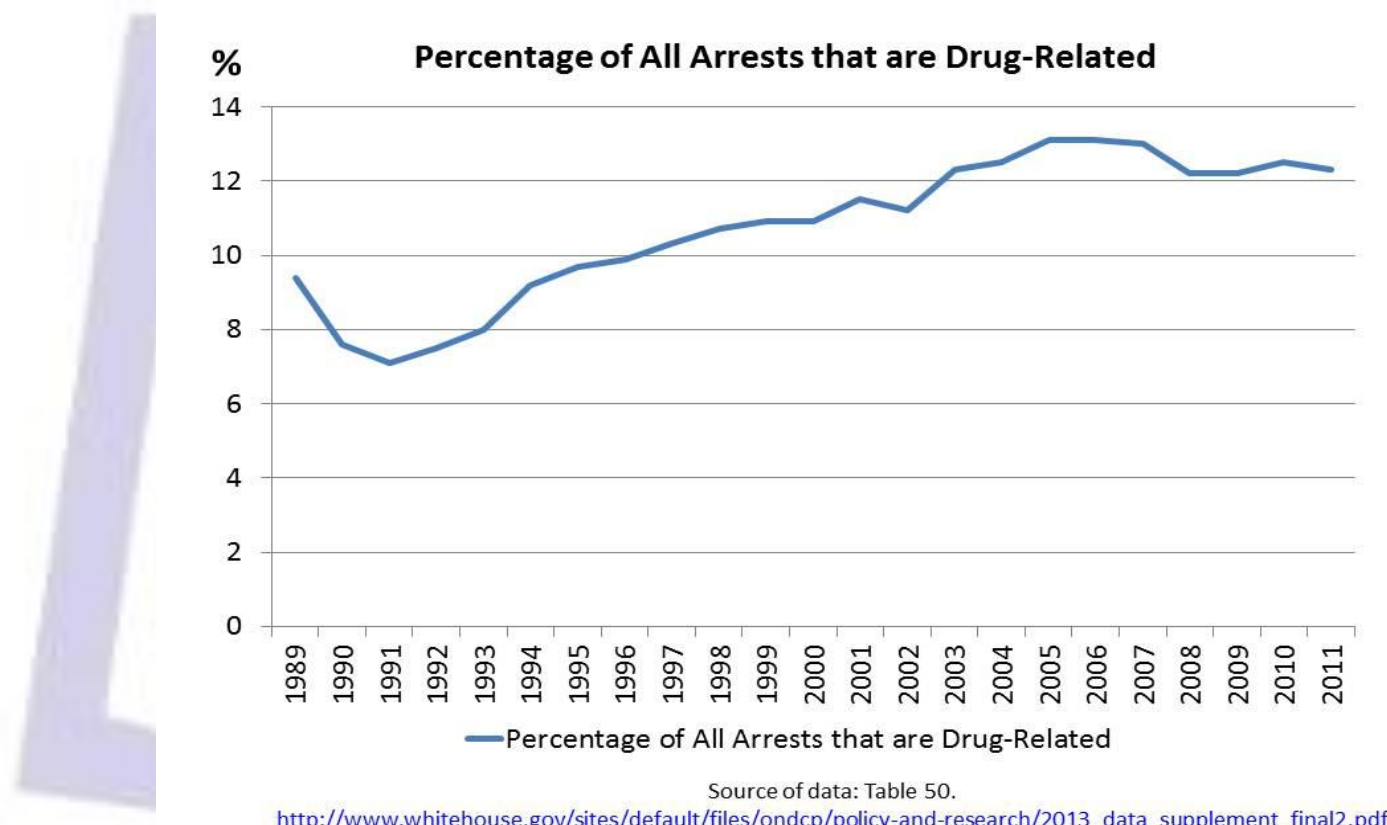

Fig 10: Law Enforcement Arrests for Drug Offenses

The percentage of offenders in American state and federal prisons is not rising over time, but the fact remains that drug offenders continue to make up a very large portion of all correctional inmates; roughly $20 \%$ of all inmates in state and federal prisons are drug offenders. This, too is a significant cost of US drug control policy.

Finally, another cost of US drug control policy is one of bias; the burden of criminal justice involvement-arrest, conviction, and incarceration-falls most heavily on poor people, people of color, and young men. Specifically, it is young, poor men of color who are most likely to be arrested, convicted, and incarcerated for drug offenses (Reiman and Leighton, 2013; Shelden, 2007; Walker, Spohn, and Delone, 2012). Table 1 demonstrates that African Americans are disproportionately impacted by the US drug war. Specifically, African Americans, who made up less than $13 \%$ of the US population in 2009 , accounted for almost $34 \%$ of all people arrested for drug violations, $44 \%$ of those convicted of drug offenses in state courts (2006), and $46 \%$ of those incarcerated in state prisons for drug offenses. Such realities do not stem from greater involvement in drug crimes and thus they are a significant threat to equality and justice in society. For example, past month use of illicit drugs for African Americans was only 9.6\% in 2009, versus $8.8 \%$ for whites (Substance Abuse and Mental Health Services Administration, 2010). 


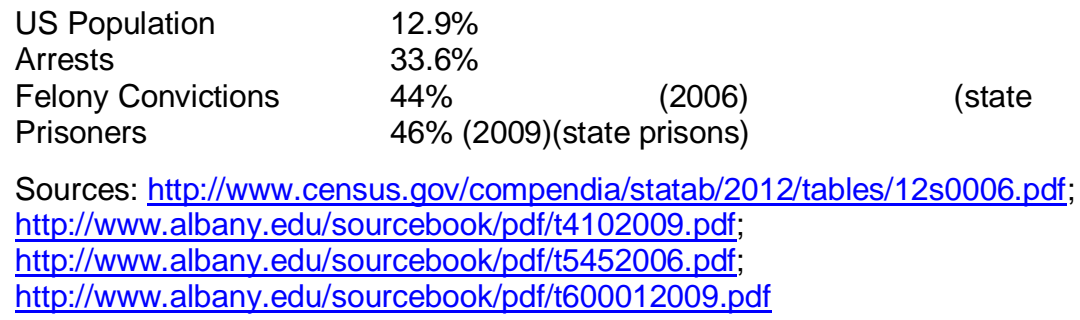

Tab1: African Americans, Drug Use, and Criminal Justice Involvement

Studies of drug enforcement have consistently illustrated that the drug war is a significant source of racial disparities in criminal justice (Alexander, 2012; Tonry, 2011). As one example, consider a study from Seattle, Washington. The authors examined drug arrests and police enforcement practices there and found that African Americans were vastly overrepresented among arrests for drug crimes in the city. Specifically, $64 \%$ of the people arrested for selling methamphetamine, ecstasy, powder cocaine, crack cocaine, and heroin were African Americans, even though the majority of people who sell these drugs are white (Beckett, Nyrop and Pflngst, 2006). Three reasons explained the fact that blacks made up a majority of those arrested even though most drug dealers are white: 1) the police focused heavily on crack cocaine (the one drug where African Americans were most involved in selling); 2) the police put more emphasis on outdoor drug venues (where African Americans were more likely to be selling); and 3) the police devoted more resources to racially heterogeneous areas (meaning far less attention to predominantly white drug dealing areas). The authors suggest that race plays either an implicit or explicit role in each of these disparity-producing factors. That is, race helps account for why police targeted certain drugs, places, or people (Beckett, Nyrop and Pflngst, 2006).

\section{WHAT DOES IT MEAN?}

A review of the publicly available data allows us to draw a very firm conclusion about US drug control policy. Stated simply, the drug war in America fails to achieve any of its stated or implied goals. Given this, it is reasonable to conclude that the drug war offers few demonstrable benefits. Meanwhile, the drug war imposes numerous costs on society and its people, including tens of billions of dollars in direct financial costs as well as more than one hundred billion in indirect costs stemming from law enforcement, courts, and correctional costs. As such, a costs-benefits analysis will surely conclude that the drug war also fails by this standard of policy analysis (MacCoun and Reuter, 2001; Miron, 2004). It is thus possible to assess the degree to which the drug war is consistent with justice. In the sections that follow, we introduce different theories of justice and then apply those theories of justice to the drug war to determine if it is consistent with any of them. The goal of the analysis is to determine if the drug war is consistent or inconsistent with social justice.

\section{THEORIES OF JUSTICE}

Earlier we defined social justice as "making sure that advantages, prizes, and rewards as well as disadvantages, burdens, and costs in society are distributed appropriately." Yet, the meaning of social justice tends to be broader because it tends to pertain to at least one of three primary concepts-welfare, freedom, and virtue (Sandel, 2009). Welfare does not refer to government handouts but instead to providing a good life for people. Freedom means protecting people's liberty. Finally, virtue is about morality.

Those who value welfare are most concerned with helping people achieve happiness, especially the majority of people, but also the most needy. Those who value freedom are most concerned with rights such as property rights and freedom from discrimination, as well as protecting civil liberties established by the Bill of Rights to the US Constitution. Finally, those who value virtue are most concerned with morality and making sure morals are reflected in societal rules and laws. Unique schools of thought about justice are associated with each of these three principles. Below we identify four theoretical approaches to justice that focus on these three principles: two stress the importance of freedom, one stresses welfare, and one stresses virtue.

\section{Utilitarianism}

Utilitarianism is focused on the concept of welfare, specifically the overall well-being and happiness of people in society. Jeremy Bentham's (1789) theory, for example, asserts that whether something is just or not depends on whether it maximizes utility or the greatest happiness for the greatest number of people. To Bentham, something is just if it promotes happiness for a majority of people; happiness is consistent with the overall welfare of society. A major criticism of utilitarianism is that it does not respect the rights of people in society. For example, if a policy that produces happiness for a majority of people in society strips individuals or a group of people of their rights, would this policy be seen as just? This is unlikely because the rights of minority groups are protected by law even when they are viewed as nontraditional or atypical. One example is religion; in the United States, people have the Constitutional right to practice whatever religion they see fit, and Congress has no authority to establish any religion (Eisgruber and Sager, 2010). Therefore, banning the right of a person or group to practice its religion, even if it contributed to happiness, would still be viewed as unjust because we also have a strong allegiance to liberty.

\section{Libertarianism}

Libertarianismholds that what matters most for justice is liberty or freedom rather than happiness or welfare. To libertarians, whether something is just or not depends on whether individual rights are respected and protected. For some, this means protecting civil rights such as the right to vote and civil liberties granted to citizens through the US Constitution 
(e.g., John Rawls, 1971). Of course, liberties are not absolute because restrictions on civil liberties are frequently made by courts when they serve other socially desirable outcomes. One criticism of this approach is thus that it is too absolute because protecting individual liberty may interfere with the government's ability to prevent crime, illegal drug use, and terrorism (Fisherand Harriger, 2013). To others, protecting liberty means assuring the right of people to pursue, own, and control property with minimal governmental interference (e.g., Friedrich Hayek, 1960; Milton Friedman, 1962; Robert Nozick, 1974). These free market libertarians favor an unregulated economic marketplace where the government does not interfere with people freely engaging in property exchanges in contexts such as employment, goods,and services. While free market libertarianism aims to protect people's property rights such as the right to enter into work agreements and to sell property, it does nothing to curb inequality in society. Free market economies tend to produce large levels of income inequality. In 2012, the top $10 \%$ of households controlled $50.4 \%$ of income and the top one percent had $19.3 \%$ of the income (Krantz, 2013). Further, the average CEO of a corporation made 273 times more money than the average employee (DePillis, 2013). Most Americans have a problem with these realities and view them as unjust because of their strong preference for equality (Miller, 2003).

\section{Egalitarianism}

Egalitarianism asserts thatwhat matters most for justice is equality of opportunity in society and taking care of the least advantaged citizens (e.g., David Miller, 2003). Whereas free market libertarians also tend to favor equality of opportunity in society (in the sense that they do not favor discrimination), egalitarians would take this one step farther and assert that governmentinvolvement in property exchanges is necessary to assure more equal outcomes in society in order to assure that the most needy are cared for. Egalitarians recognize that superior talent and effort will result in superior reward, but they tend to believe that today's inequalities are not justifiable (Miller, 2003).

A criticism of egalitarianism is that it is seen by some as a restriction of individual liberty. Coercing rich people to pay higher taxes, mandating a minimum wage, or even telling companies that they must do something in particular is seen by some as a violation of freedom (Pollin, Brenner, Luce, and Wicks-Lim, 2008).

\section{Virtue-based theories}

Virtue-based theories are diverse but share the belief that what matters most for justice isvirtue, or moral goodness and righteousness. One example of this approach is Immanuel Kant (1785), who asserted that whether something is just or not depends only whether it is the right thing to do, regardless of the consequences. To Kant, something is just if it is motivated by morality. Something is morally right, according to Kant, if it respects the moral law which requires us to treat each other as autonomous beings worthy of respect.

A limitation of this approach is who gets to decide what is moral or virtuous? Since public opinion on issues such as abortion, drugs, taxes, and capital punishment is varied, who decides what is moral and immoral (Amaya and Lai, 2013; MacIntyre,

\section{WHICH THEORIES OF JUSTICE ARE RELEVANT FOR THE DRUG WAR?}

2007)?

Which theories of justice are relevant for the drug war? To a utilitarian, the most important issue in deciding if the drug war is just is determining whether national drug control policy contributes to overall happiness in society. If it could be shown that the drug war achieves undeniable benefits that contribute to the overall happiness in society (such as reducing drug abuse and addiction as well as drug-related crimes), then utilitarians would likely see the drug war as just; if not, they would see it as unjust (Inciardi, 2007; Kleiman, Caulkins, and Hawken, 2011).

To a libertarian, the major issue would be whether the drug war respects liberty or freedom. In a free society, shouldn't a person be able to experiment with and responsibly use drugs, as long as he or she does not hurt another innocent person? If so, libertarians would likely see the drug war as unjust (Boyum and Reuter, 2005). If it could be shown that the drug war helps protect liberty (e.g., freedom from drug abuse), then libertarians would see the drug war as just. But, isn't drug use-especially illegal drug use_immoral or wrong? A person concerned with virtue might say so, and in this case, the drug war would be seen as socially just. But of course, the issue of whether the drug war itself is virtuous or moral would also be important to know (Inciardi, 2007; Yardley, 2014).

Finally, to an egalitarian the most important question would be whether the drug war is applied equally or unequally in society. If the drug war is fought largely in inner-city areas inhabited by the poor and people of color, egalitarians would characterize the drug war as unjust; if it helped protect people equally, they may see it as just (Inciardi, 2007; Provine, 2007).

\section{APPLYING THEORIES OF JUSTICE TO THE DRUG WAR}

Given the realities of the drug war, the next portion of analysis addresses the relevance of 'justice' as it is applied to the drug war. Whether the drug war is considered just or unjust depends on which theory of justice is being used.

\section{Utility/Utilitarianism}

Does the drug war contribute to the overall happiness of society, to the general welfare of the majority? The answer appears to be no. First, none of the goals and objectives of the drug war are being met consistently. Second, the drug war imposes enormous costs on society. Some of these are financial, others are social (e.g., class and race disparities in arrests, convictions, and correctional punishment). We thus suspect utilitarians would reject the drug war on the grounds that it is unjust. 
If the goals of the drug war were being achieved so that there was less drug use and abuse, one could argue the drug war is just because it would contribute to societal welfare and overall happiness. Yet, if using drugs makes people happyespecially in cases that do not harm other people-a utilitarian would argue that restricting the ability of people to use the drug of their choice does not promote happiness in society. Just as people may have a drink of alcohol after a hard day or with friends at "happy hour," a utilitarian might suggest that a person should also be able to responsibly smoke a joint of marijuana or pop a pill of his or her drug of choice, for the sake of happiness, as such acts do not impose more harm on society than they produce happiness. That drug use is normal and has been in nearly all societies in human history strengthens this latter argument (Inciardi, 2007). As we showed in this paper, drugs remain readily available to American youth and in cases where the drug war has reduced availability of some drugs, young people are merely switching to other, more dangerous drugs (i.e., prescription drugs), a reality that does not contribute to overall happiness. The drug war is also not effectively healing drug abusers because sufficient funds are not being distributed to drug treatment facilities, but instead to prisons. Finally, the costs of drugs to society are consistently rising. For each of these reasons, the drug war is not contributing to our overall well-being or happiness. This is not to say that the drug war does not achieve any benefits to society. By apprehending drug users, abusers, and dealers it does get a portion of offenders off the streets. But these offenders are created in the first place by drug prohibition, and there is no evidence that these people are not simply replaced by other users, abusers, and dealers. And of course, criminal justice operations are costly to taxpayers, a major concern

libertarians.

\section{Liberty/Libertarianism}

Does the pursuit of the drug war promote liberty to the individual and prioritize freedom to individuals? If the drug war protects us from harms committed by others, then the answer may be yes. If the drug war leads to arrest, conviction, and incarceration of drug users who are doing no harm to others, and the dealers that provide them with their drugs of choice, then the answer is likely no. Libertarians believe that the state should not set moral legislation, which is at the heart of the drug war (Sandel, 2009). Many supporters of the drug war argue that using drugs is not only illegal but immoral, consistent with virtue-based approaches. Yet, libertarianism does not promote a paternalism state. Instead, libertarianism prioritizes the individual's right to choose how he or she lives his or her life. If an individual wants to consume drugs, then one should have that right so long as it does not interfere with the rights of others. As noted in the Declaration of Independence: "We hold these truths to be self-evident, that all men are created equal, that they are endowed by their Creator with certain unalienable Rights, that among these are Life, Liberty and the pursuit of Happiness" (US History, 2010, emphasis added). The drug war largely fails to respect liberty because it interferes with the individual's ability to decide for himself or herself what to put in his or her body. Given that drug use is normal and mostly recreational and non-problematic, there is little reason to define drug possession and use as crimes. It is only when drug users hurt others that it should come to the attention of the criminal law and criminal justice system (Gray, 2001). Of course, libertarians might support policies if they prevent harms committed by some people against other people, for those harms restrict the liberties or freedoms of victims. There is clearly crime and violence associated with drug use and the illicit drug market. Incredibly, analyses consistently illustrate that the great bulk of crimes associated with drugs are produced not by drug use but instead by drug policy itself; the most striking example are economic compulsive and systemic crimes produced in the black market created by drug prohibition (Robinson and Scherlen, 2014). For these reasons, we suspect libertarians would generally reject the drug war on the grounds that it is unjust.

\section{Equality/Egalitarianism}

For egalitarians, the central issue of concern is equality. In two ways, the drug war is a threat to equality. First, there are significant class, race, and gender disparities in the enforcement of drug laws, making US drug control policy a significant threat to equality in society. It is poor, young, men of color who are most likely to be arrested, convicted, and punished for drug offenses, as noted earlier. Scholars have suggested there are both systematic and contextual biases in which drugs are prosecuted more frequently with harsher sentences for some offenders than others, as in the case of powder-cocaine and crack-cocaine offenders (Alexander, 2012; Walker, Spohn, and DeLone, 2011). Biases starting with the laws carry over into policing so that police officers arrest at much higher rates poor, black men even as evidence from national data sources shows that these men do not use drugs at a drastically higher rate than their white counterparts (Robinson and Scherlen, 2014). The second way the drug war is a threat to equality is that, with conviction comes diminished opportunity to participate in the legal economy as well as democratic citizenship (e.g., voting). People convicted of relatively minor drug crimes are unable to find work upon release from jail and prison, and millions are not allowed to vote as a result of their convictions (Cheung, 2013). This is a serious threat to equality in society and in fact serves to interfere with other laws aimed at assuring equal treatment in society (Alexander, 2012). For these reasons, we suspect egalitarians would reject the drug war on the grounds that it is unjust.

\section{Virtue/Virtue-Based Theories}

With regard to virtue-based theories, what is important is does the pursuit of the drug war promote Americans' values, moral goodness, and is the right thing to do? These questions are difficult to answer, given American values widely vary when it comes to different circumstances and contexts (Miller, 2003). As noted earlier, some people view drug use itself as immoral. To those people, the drug war is likely seen as just even though few of them likely abstain from use of all drugs themselves.

Yet, given the drug war was found to be unjust in the theories of utilitarianism, libertarianism and egalitarianism, a relevant question is, on which values would the drug war be justified? That is, since the drug war does not, in practice, promote welfare, liberty, or equality, on what value or virtue can it be considered just? We find it hard to argue that drug use itself if inherently immoral since so many Americans use drugs to wake up in the morning (e.g., caffeine in coffee), relax after work (e.g., alcohol), fall asleep at night (e.g., prescription or over the counter medicine), as well as to experiment with illicit 
drug use as teenagers and young adults (i.e., about $50 \%$ of Americans admit to having tried an illegal drug at least once in their lifetime).

Finally, it is important to note that ONDCP's historic failure to present and fairly analyze all relevant statistics related to its goals and objectives runs counter to principles of honesty and fair play. The kind of analysis illustrated in this paper is more complete than that offered each year in the National Drug Control Strategy; rather than offering all the data and conducting a complete an fair analysis to determine if the drug war is achieving its goals, ONDCP instead selectively presents limited data and visual evidence (while ignoring the rest) to make the argument that the drug war is working. We suspect that virtue-based theorists would hold this to be immoral and thus inconsistent with justice.

\section{CONCLUSION}

In this paper, we've shown that the US drug war does not consistently reduce drug use and abuse among young people and adults. Further, in spite of the fact that some illicit drugs are slightly less available now than prior to the established of the Office of National Drug Control Policy (ONDCP), most illicit drugs are still easily accessible. US drug control policy also fails to heal drug abusers by providing treatment to those who need it; this is largely due to imbalances in spending in favor of supply-side measure over demand-side measures and a general unwillingness to frame drug abuse as a medical problem rather than a criminal justice issue. Finally, the drug war fails to reduce health and social costs to society; instead, deaths and illnesses associated with drugs continue to rise, as does spending on the drug war. These findings speak directly to the fact that the drug war has little utility, especially relative to the costs it imposes. As such, the utilitarian argument is that the drug war is unjust; US drug control policy does not contribute to societal welfare and the overall happiness of people. It is obvious that the drug war does not respect liberty, as US laws restrict the ability of people to use certain drugs while allowing them to use the most dangerous drugs. The government does this in the name of public safety, yet the most dangerous drugs are not included in its drug laws. Thus, the libertarian argument is that they drug war is unjust. Further, the costs of US drug control are enormous and growing; thus free market libertarians would likely reject the drug war as unjust as well. The application of US drug control laws are not applied equally, and thus they threaten equality in society. Specifically, it is poor and minority users and sellers who are most victimized by the drug war. They not only face the greatest threats to their liberty, they also are most likely to suffer from diminished opportunity to pursue wealth legally as a result of their arrests and convictions for drug crimes and to participate in democracy. Thus, the egalitarian argument is that the drug war is unjust. Finally, is the drug war virtuous? While we recognize that some people continue to view drug use as immoral and thus the drug war as virtuous, on what virtues can drug prohibition be justified when it fails to assure happiness, liberty, and equality?Further, what virtues can possibly justify ONDCP's manipulation and selective presentation of data to argue that the drug war is working when its own data clearly show that it is not?

\section{References}

[1] Alexander, M. (2012). The New Jim Crow: Mass Incarceration in the Age of Colorblindness. New York: The New Press.

[2] Amaya, A., and Lai, H. (2013). Law, Virtue and Justice. Oxford, UK: Hart.

[3] Beckett, K., Nyrop, K.,andPflngst, L. (2006). Race, drugs, and policing: Understanding disparities in drug delivery arrests. Criminology44, 105-137.

[4] Benavie, A. (2008). Drugs: America's Holy War. New York: Routledge.

[5] Bennett, B. (2014). Truth: The Anti-Drug War. Retrieved from:http://www.briancbennett.com

[6] Bentham, J. (1789). AnIntroduction to the Principles of Morals and Legislation. New York:Oxford University Press.

[7] Boyum, D., and Reuter, B. (2005). An Analytic Assessment of US Drug Policy. Washington, DC:AEI Press.

[8] Brown, Z. (2014). Black, white, and Hispanic males are getting arrested at insane rates in drugwar. PolicyMic, January

15. Retrieved from: http://www.policymic.com/articles/78817/black-white-and-hispanic-males-are-getting arrested-at-insane-rates-in-drug-war

[9] Bureau of Justice Statistics (2008). Drug and crime facts. Retrieved from:http://www.bjs.gov/content/dcf/enforce.cfm [10] Cheung, J. (2013). Felony Disenfranchisement: A Primer. Washington, DC: Sentencing Project.

[11] DePillis, L. (2013). Congrats, CEOs! You're making 273 times the pay of the average worker.Washington Post, January

26. Retrieved from: http://www.washingtonpost.com/blogs/wonkblog/wp/2013/06/26/congrats-ceos-youre- making-273times-the-pay-of-the-average-worker/

[12] Eisgruber, C., and Sager, L. (2010). Religious Freedom and the Constitution. Harvard, MA:Harvard University Press.

[13] Fisher, K., and Harriger, L. (2013). American Constitutional Law. Durham, NC: Carolina Academic Press.

[14] Friedman, M. (1962). Capitalism and Freedom. Chicago, IL: University of Chicago Press.

[15] Gallup (2013). For first time, Americans support favoring legalization. October 22. Retrieved from: http://www.gallup.com/poll/165539/first-time-americans-favor-legalizing-marijuana.aspx 
[16] Gray, J. (2001). Why our Drug Laws Have Failed and What We Can Do About It: A Judicial Indictment of the Drug War. Philadelphia, PA: Temple University Press.

[17] Hayek, F. (1960). The Constitution of Liberty. Chicago, IL: University of Chicago Press.

[18] Inciardi, J. (2007). The War on Drugs IV: The Continuing Sage of the Mysteries and Miseries of Intoxication,

Addiction, Crime, and Public Policy. Upper Saddle River, NJ: Pearson.

[19] Kant, I. (1785). Groundwork for the Metaphysical of Morals. New York: Broadview Press.

[20] Kleiman, M., Caulkins, J., and Hawken, A. (2011). Drugs and Drug Policy: What Everyone Needs to Know. New York: Oxford University Press.

[21] Krantz, M. (2013). Top 1\% take biggest income slice on record. USA Today, September 10. Retrieved from: http://www.usatoday.com/story/money/business/2013/09/10/pay-gap-richest-poorest/2793343/

[22] MacCoun, R., and Reuter, P. (2001). Drug War Heresies: Learning from Other Vices, Times, and Places. Washington, DC: Rand.

[23] MacIntyre, A. (2007). After Virtue: A Study in Moral Theory. Notre Dame, IN: University of Notre Dame. [24] Miller, D. (2003). Principles of Social Justice. Harvard, MA: Harvard University Press.

[25] Miron, J. (2004). Drug War Crimes: The Consequences of Prohibition. Washington, DC:Independent Institute.

[26] Miron, J., and Waldock, K. (2010). The Budgetary Implications of Ending Drug Prohibition.Washington, DC: CATO Institute.

[27] National Institute of Drug Abuse (2014). Addiction science: From molecules to managed care. Retrieved from: http://www.drugabuse.gov/publications/addiction-science/relapse/drug-abuse-treatment-works-brings-about-reductionsnot-just-in-drug-abuse-also-in-crim

[28] Nozick, R. (1974). Anarchy, State, and Utopia. New York: Basic Books.

[29] Office of National Drug Control Policy (2014). National Drug Control Strategy. Retrieved from: http://www.whitehouse.gov/ondcp/2013-national-drug-control-strategy

[30] Pollin, R., Brenner, M., Luce, S., and Wicks-Lim, J. (2008). A Measure of Fairness: The Economics of Living Wages and Minimum Wages in the United States. Ithaca, NY: ILR Press.

[31] Provine, D. (2007). Unequal Under the Law: Race in the War on Drugs. Chicago, IL: University of Chicago Press. [32] Rawls, J. (1971). A Theory of Justice. New York: Belknap.

[33] Reiman, J., and Leighton, P. (2013). The Rich Get Richer and the Poor Get Prison: Ideology, Class, and Criminal Justice. Upper Saddle River, NJ: Pearson.

[34] Robinson, M.,and Scherlen, R. (2014). Lies, Damned Lies, and Drug War Statistics: A Critical Analysis of Claims Made

by the Office of National Drug Control Policy, Second Edition. Albany, NY: SUNY Press.

[35] Robinson, M., and Scherlen, R. (2007). Lies, Damned Lies, and Drug War Statistics: A Critical Analysis of Claims Made by the Office of National Drug Control Policy. Albany, NY: SUNY Press.

[36]Sandel, M. (2009). Justice: What is the Right Thing to Do? New York: Farrar, Straus and Giroux. [37]Shelden, R. (2007). Controlling the Dangerous Classes: A History of Criminal Justice in America.Boston, MA: Allyn and Bacon.

[38]Substance Abuse and Mental Health Services Administration (2010). Results from the 2009National Survey on Drug Use and Health: Volume I. Summary of National Findings. Retrieved from:

http://samhsa.gov/data/NSDUH/2k9NSDUH/2k9Results.htm\#2.7

[39]Tonry, M. (2011). Punishing Race. New York: Oxford University Press.

[40]US History (2010). Declaration of Independence. Retrieved from:

http://www.archives.gov/exhibits/charters/declaration_transcript.html

[41]Vance, L. (2014). The War on Drugs is a War on Freedom. Vance publications.

[42] Yardley, T. (2012). Why We Take Drugs: Seeking Excess and Communion in the Modern World.New York: Routledge.

[43]Walker, S., Spohn, C., and Delone, M. (2012). The Color of Justice: Race, Ethnicity, and Crime in America. Belmont, 
A: Wadsworth.

\section{Author's biography with Photo}

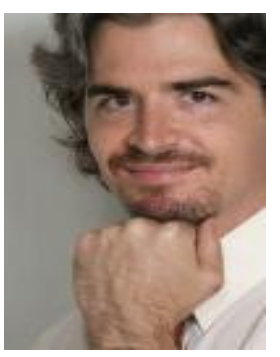

Matthew Robinson received his PhD in Criminology \& Criminal Justice from the Florida State University in 1997 and then joined the faculty at Appalachian State University (ASU) in Boone, NC. He is Professor in the Department of Government and Justice Studies at ASU, teaching and doing research primarily in the areas of criminological theory, capital punishment, national drug control policy, media studies, and social justice. He is the author of seventeen books as well as about 100 other articles, chapters, and other writings on these topics. Robinson is Past President of the Southern Criminal Justice Association (SCJA) and the North Carolina Criminal Justice Association (NCCJA). Maggie Jones received her Master of Criminal Justice and Criminology (MSCJC) from Appalachian State University in December 2014. She writes about social justice as it pertains to the drug war as well as issues impacting the US military. 